【論文】

\title{
誘電体多層膜を用いた宇宙用熱制御材料の 熱光学特性評価 \\ Evaluation of Thermal Control Material using Dielectric Multi-layer Film for Spacecraft
}

\author{
富岡孝太* 太刀川純孝** 長坂雄次*** \\ Kota Tomioka, Sumitaka Tachikawa and Yuji Nagasaka
}

\begin{abstract}
従来の宇宙機用ラジエータ材は太陽光を反射する目的で金属を含む材料を一般に用いていたため, 電波透過面に適用することは出来ない，そこで，金属を用いず低太陽光吸収率を示し，かつ，高全半 球放射率を示す新しい電波透過型宇宙用熱制御材 COSF(Controlled Optical Surface Film)を開発してい る．本材料は，而宇宙環境性に優れたポリイミドフィルムを基板とし，その表面には誘電体多層膜が 成膜されている，多層膜の膜厚は遺伝的アルゴリズムを用いて設計し，低太陽光吸収率及び高全半球 放射率となるように，評価関数を設定した，本論文では，熱光学特性に関する設計方法及び測定結果 について報告する。
\end{abstract}

Conventional radiators for spacecraft usually consist of metal materials with their high reflectance for the solar light. However, they also simultaneously reflect radio waves and cannot be applied for the path of radio waves. Then, we have developed a new radio wave transmissive thermal control mirror, COSF (Controlled Optical Surface Film) which shows a low solar absorptance and a high total hemispherical emittance. This material is composed of dielectric multilayers on a polyimide film. The thickness of each layer is designed by genetic algorithm. The merit function is set to be a low solar absorptance and a high total hemispherical emittance. This paper presents a design method and measurement results about the thermo-optical properties of COSF.

[Keywords: Spacecraft thermal control, Thermo-optical properties, Genetic algorithm, Radiator]

\section{1.はじめに}

宇宙機の温度は，使用されている熱制御材料の熱光学 特性（太陽光吸収率 $\alpha_{\mathrm{N}}{ }^{\text {total }}$ (solar), 全半球放射率 $\varepsilon_{\mathrm{H}}{ }_{\mathrm{H}}^{\text {total }}(T)$ ) に よって決まるため, 熱光学特性を自由に選択できること は熱設計上重要である。 また，通信用アンテナや無線電

* 名古屋大学大学院工学研究科 機械システム工学専攻,

干464-8603 名古屋市千種区不老町.

Department of Mechanical System Engineering, Nagoya University, Furo, Chikusa, Nagoya, Nagoya 464-8603.

TEL: 052-789-2739 E-mail: kota.tomioka@mae.nagoya-u.ac.jp

** 宇宙航空研究開発機構宇宙科学研究所,

テ252-5210 神奈川県相模原市中央区由野台 3-1-1.

Japan Aerospace Exploration Agency, Institute of Space and Astronautical Science, 3-1-1, Yoshinodai, Sagamihara, Kanagawa, 252-5210.

FAX: 042-759-8349 E-mail: sumitaka@isas.jaxa.jp

***慶應義塾大学理工学部システムデザイン工学科,

干223-8522 横浜市港北区日吉 3-14-1.

Department of System Design Engineering, Keio University, 3-14-1

Hiyoshi, Yokohama, Kanagawa, 223-8522.

E-mail: nagasaka@sd.keio.ac.jp
力・信号伝送用のアンテナの熱制御に対しては, 熱光学特 性と電波透過性の両方の機能が求められる. しかし, 一般 的な宇宙用熱制御材料は低太陽光吸収率を実現するため 金属材料を使用しており，電波透過性は無く，また，材料 自身の特性によって熱光学特性が決まるので, 選択の自 由度が少なかった. そこで, 我々は誘電体多層膜の干渉を 使って熱光学特性を自由に設計できる電波透過型熱制御 材料 COSF（Controlled Optical Surface Film）を提案し[1], 低太陽光吸収率及び高全半球放射率という特性を備えた 排熱用 COSF の開発を行ってきた[2]. 今回，使用する薄 膜材料の光学定数測定を新たに行い，その特性を最大限 に生かすように遺伝的アルゴリズムを使って設計するこ とによって, 従来の排熱用熱制御材料を超える性能を示 寸結果が得られた. 本論文では, その設計方法及び熱光学 特性測定結果について報告する. 


\section{2. 設計方法}

\section{2. $1 \operatorname{COSF}$ の構造}

COSF の基本構造を, 従来の排熱用熱制御材料である OSR (Optical Solar Reflector) と比較する. Figures 1(a), (b)は それぞれ OSR，COSF の構造を示している. OSR は，石 英やホウケイ酸ガラスの裹面に $\mathrm{Al}$ や $\mathrm{Ag}$ を蒸着した二次 鏡面材料である.ガラスを透過した太陽光は金属表面で 殆ど反射されるため, 低太陽光吸収率を示し, 宇宙機から 伝わる熱は高い赤外放射率を示すガラス表面からふく射 によって放熱される. 一方, COSF は Fig. 1(b)のように， ポリイミドフィルムの A 面 (宇宙側) あるいはB 面（宇 宙機側）に誘電体多層膜を成膜したものを基本的な構造 とする. 多層膜内において, 太陽光波長域 $(0.25 \sim 2.5 \mu \mathrm{m})$ 及び赤外放射波長域（1.67～100 $\mu \mathrm{m} ）$ の干涉を生じさせ， 膜材料や膜厚を適切に選択することによって，分光反射 率, 吸収率, 透過率を自由に設計できる. その結果, 太陽 光吸収率と赤外放射率を自由に選択できる. また, 金属を 使用していないため, 電波透過性を示すとともに[1], 基板 にはフレキシブル基材を使用しているため, 従来のガラ ス製 OSR と異なり, 曲面に取り付けることが可能である.

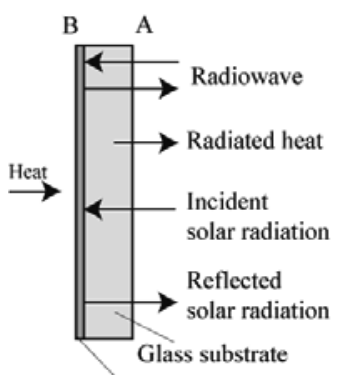

Metal coating $(\mathrm{Ag})$

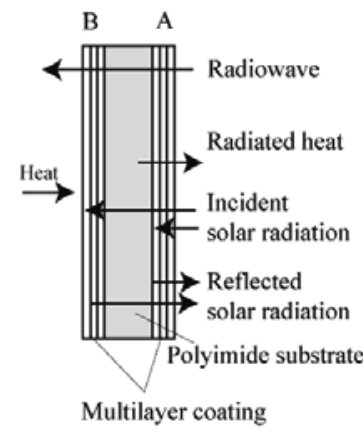

(b) $\mathrm{COSF}$
Fig. 1 Schematic of basic mechanism of OSR and COSF.

\section{2 光学定数}

多層膜で大きな干渉を起こすためには，基本的に高屈 折率材料と低屈折率材料が必要となる. そこで, 蒸着材料 の候補材料として, 高屈折材料として $\mathrm{Ta}_{2} \mathrm{O}_{5}, \mathrm{TiO}_{2}, \mathrm{Si}$, 低 屈折材として $\mathrm{SiO}_{2}$ を選定した. いずれも蒸着材料として 実績のある材料である. 光学特性は蒸着方法, 真空度, 基 板温度, 成膜レートに強く依存するため, 実際に厚さ500 $\mathrm{nm}$ の単層膜を $\mathrm{Si}$ 基板上に成膜し, 分光エリプソメトリー （J.A. Woolam Co. Inc.,: M-2000UI, IRVASE）を用いて，屈

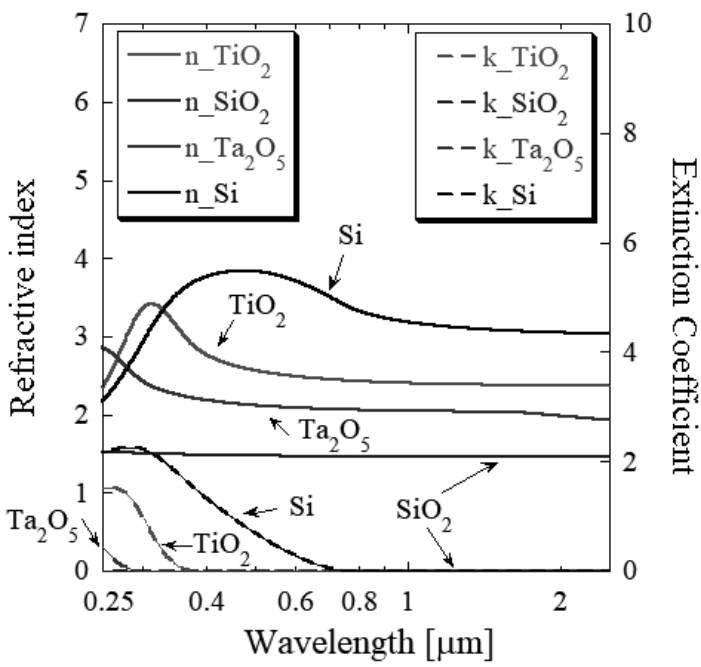

Fig. 2 Optical Constants of thin layers.

$(0.25 \sim 2.5 \mu \mathrm{m})$

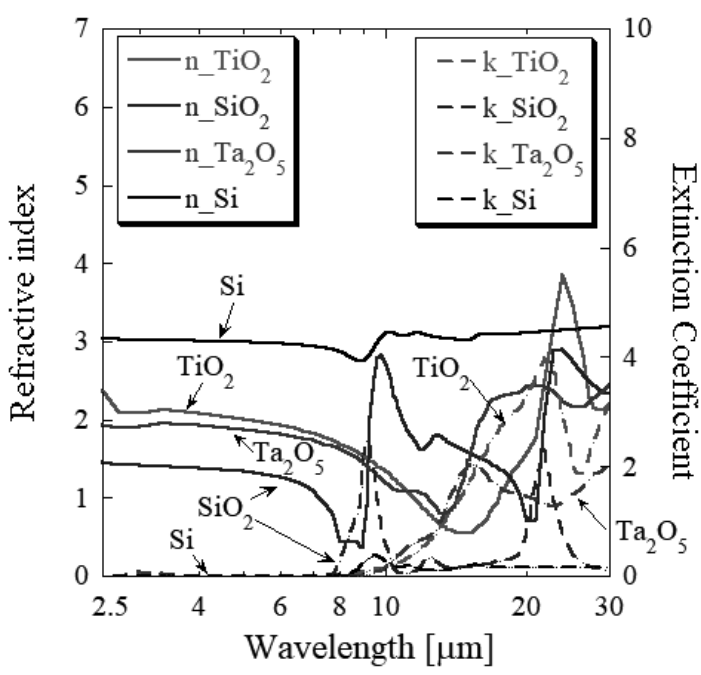

Fig. 3 Optical Constants of thin layers.

$(2.5 \sim 30 \mu \mathrm{m})$

折率と消衰係数の測定を行った.

Figure 2 に太陽光波長域 $(0.25 \sim 2.5 \mu \mathrm{m}) ，$ Fig. 3に赤外 放射波長域の一部分 $(2.5 \sim 30 \mu \mathrm{m})$ における測定結果を示 す．排熱用COSFは，太陽光波長域では高反射である必要 がある. Si は0.8 $\mu \mathrm{m}$ 以前では吸収があるが，全体的に高 屈折な材料である. $\mathrm{TiO}_{2}$ は太陽から来るふく射エネルギー

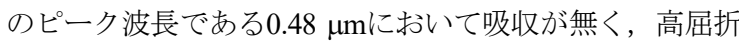
な材料である. $\mathrm{Ta}_{2} \mathrm{O}_{5}$ は $\mathrm{Si} や \mathrm{TiO}_{2}$ と比べると低屈折率であ るが，最も吸収の少ない材料であることが分かる。一方， 赤外放射波長域では低反射である必要がある. Si以外の膜 材の赤外域の消衰係数が増加しているため, 膜厚を厚く 
することによって吸収を増加させることができる．各膜 材の $30 \mu \mathrm{m}$ 以降の光学定数は文献[3]から, UPILEX-Sの光 学定数については文献[4]から引用した.

\section{3 設計方法および結果}

多層膜設計には遺伝的アルゴリズム（GA）を用いた $[1$, 5]. GA は, 全探索が不可能と考えられるほど広大な解空 間を持つ問題に有効である一方, 局所解に陥ると極小值 から脱出するには確率に依存するため, 有効な解を導き 出すことが困難になる. そこで, なるべく少ない層数で性 能を達成させるために, 膜材の光学定数から熱光学的に 有効な多層膜構造に収束するような評価関数を GA に加 えた. 本研究では, 低い太陽光吸収率 $\alpha_{\mathbb{N}}{ }^{\text {total }}$ (solar)を示寸多 層膜構造が優位になるように設定している。これは宇宙 機の温度が太陽光吸収率を放射率で割った $\alpha_{\mathbb{N}}{ }^{\text {total }}$ (solar) / $\mathcal{E}_{\mathrm{H}}{ }^{\text {total }}(T)$ によって決定されるため， $\alpha_{\mathbb{N}}^{\text {total }}($ solar $)$ を小さくし たほうが, 効果があるためである. Figures 4, 5 に狙いの多 層膜構造および太陽光波長域での分光反射率の特性を示 す. 各面（A-1～A-3 面）では，異なる太陽光波長域にお いて高反射を示す特性を持つ. $0.25 \sim 0.3 \mu \mathrm{m}$ の光は A-1 面 の $\mathrm{Ta}_{2} \mathrm{O}_{5} / \mathrm{SiO}_{2}$ によって反射し，0.3 $\mu \mathrm{m}$ 以降の光は A-1 面 を透過する. 透過した光のうち $0.3 \sim 0.8 \mu \mathrm{m}$ の光は A-2 面 である $\mathrm{TiO}_{2} / \mathrm{SiO}_{2}$ で反射し, 残りの $0.8 \sim 2.5 \mu \mathrm{m}$ の光は A3 面である $\mathrm{Si} / \mathrm{SiO}_{2}$ によって反射している. 各スタックは Fig. 2 に示すように膜材の消衰係数がほぼ 0 である波長区 間を担当しており，また，太陽光を短波長側から順に反射 する構成とすることでなるべく吸収を小さくし，低太陽 光吸収率となるように構成されている. 各面には Eq. (1) (3)に示すような異なる評価関数 $E\left(\alpha_{\mathbb{N}}{ }^{\text {partial }}(\right.$ solar $\left.),{ }_{\mathrm{H}_{\mathrm{H}}}^{\text {total }}(T)\right)$ を 設定することで，低太陽光吸収率および高放射率な材料 を設計した. Eq. (1)は波長積分区間 $a \sim b \mu \mathrm{m}$ における太陽 光吸収率を表しており, 右辺の分母は入射する太陽光工 ネルギーを表しているのに対し, 分子は材料が吸収する エネルギーを表している．ただし，A-1 面の場合 $a=0.25$ $\mu \mathrm{m}, b=0.3 \mu \mathrm{m}, \mathrm{A}-2$ 面の場合 $a=0.3 \mu \mathrm{m}, b=0.8 \mu \mathrm{m}, \mathrm{A}-3$ 面の場合 $a=0.8 \mu \mathrm{m}, b=2.5 \mu \mathrm{m}$ であり, 実測より求められ た AM0 の太陽光強度スペクトル $J(\lambda)$ を使用している[6]. Eq. (2)は, 材料の全半球放射率を表しており, 右辺の分母 は理想黒体面の全半球放射エネルギーに対し, 分子は材 料の全半球放射エネルギーを表している. 本研究では $T=$ $300 \mathrm{~K}$ として計算を行った. また，Eq. (3)は評価関数を表 しており，太陽光吸収率を放射率で割った值とすること

$$
\alpha_{\mathrm{N}}^{\text {partial }}(\text { solar })=\frac{\int_{a}^{b}\left\{1-R_{\mathrm{NH}}(\lambda)\right\} J(\lambda) d \lambda}{\int_{a}^{b} J(\lambda) d \lambda}
$$

$$
\varepsilon_{\mathrm{H}}^{\text {total }}(T)
$$$$
=\frac{\int_{0}^{\pi / 2} \int_{1.67 \mu \mathrm{m}}^{100 \mu \mathrm{m}}\left\{1-R_{\mathrm{NH}}(\lambda, \theta)\right\} I_{\mathrm{B}}(\lambda, T) \cos \theta \sin \theta d \lambda d \theta}{\int_{0}^{\pi / 2} \int_{1.67 \mu \mathrm{m}}^{100 \mu \mathrm{m}} I_{\mathrm{B}}(\lambda, T) \cos \theta \sin \theta d \lambda d \theta}
$$

$$
E\left(\alpha_{\mathrm{N}}^{\text {partial }}(\text { solar }), \varepsilon_{\mathrm{H}}^{\text {total }}(T)\right)=\frac{\alpha_{\mathrm{N}}^{\text {partial }}(\text { solar })}{\varepsilon_{\mathrm{H}}^{\text {total }}(T)}
$$

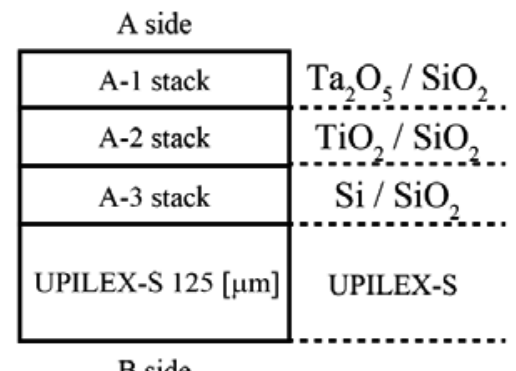

Fig. 4 Target structure of COSF for waste heat.

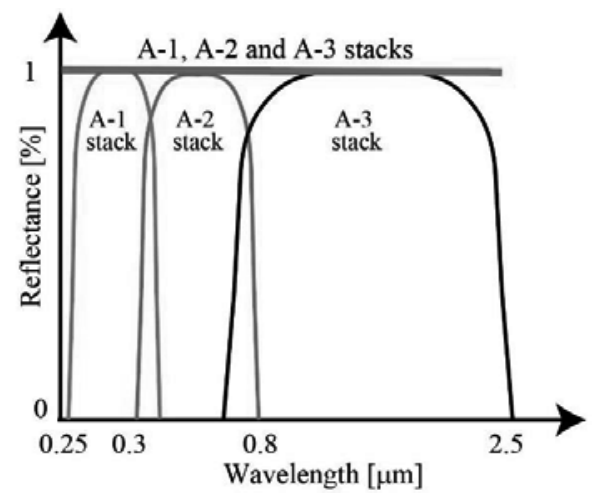

Fig. 5 Target spectral reflectance of each layer.

で，なるべく材料自身の温度が下がるような構成を目指 した.

上記設計方法を用いて排熱用 COSF4-RE を試作した.

Figure 6 に COSF4-RE の太陽光波長域における, 多層膜全 体（A-1, 2, 3 面），A-2, 3 面のみ，A-3 面のみで構成した 3 種類の場合の反射スペクトルの設計值および, 太陽光の 強度スペクトルを示寸. A-3 面のみの場合の反射スペクト ルは， $0.8 \sim 2.5 \mu \mathrm{m}$ 付近で反射率が高くなっていることが 分かる.また，A-2 面を追加することで可視光域，A-1 面 を追加することで紫外域の反射率が向上していることが 分かる.このことから, A-1 面では $0.25 \sim 0.3 \mu \mathrm{m}$ の光を反 射し，A-2 面では $0.3 \sim 0.8 \mu \mathrm{m}$ の光を反射，A-3 面では残 


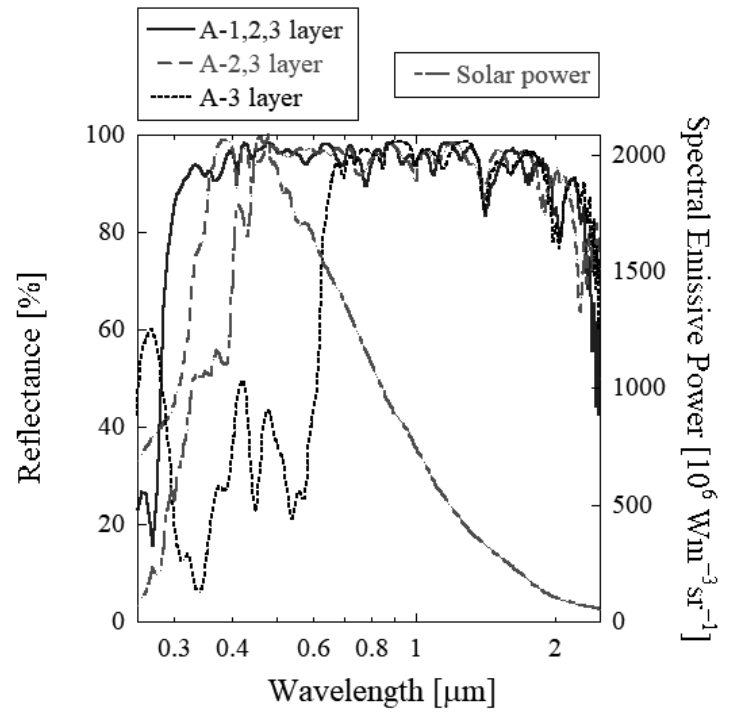

Fig. 6 Design results of spectral reflectance.

$(0.25 \sim 2.5 \mu \mathrm{m})$

りの透過した $0.8 \sim 2.5 \mu \mathrm{m}$ の光を反射するという，狙いと した膜構造が出来ていることが分かった. また, 太陽から 来るふく射エネルギーのピーク波長である $0.48 \mu \mathrm{m}$ を中心 として, 高い反射率を示していることが分かる.

Table 1 に COSF-4RE の多層膜の総膜厚, 層数, 太陽光 吸収率 $\alpha_{\mathrm{N}}{ }^{\text {total }}$ (solar), 全垂直放射率 $\varepsilon_{\mathrm{N}}{ }^{\text {total }}(300 \mathrm{~K})$, 全半球放射 率 $8_{\mathrm{H}}{ }^{\text {total }}(300 \mathrm{~K})$ についてまとめる。基板には UPILEX-S 125 $\mu \mathrm{m}$ を使用し, $\mathrm{A}$ 面に片面蒸着した. 薄膜部分の全膜厚は $3.72 \mu \mathrm{m}$ である. 太陽光吸収率は 0.05 と非常に小さな值を 示しており，また， $300 \mathrm{~K}$ における全垂直放射率は 0.80 , 全半球放射率は 0.74 と高い值を示している. 従来の排熱 材料である OSR の熱光学特性 $\left(\alpha_{\mathrm{N}}{ }^{\text {total }}(\right.$ solar $)=0.07, \varepsilon_{\mathrm{H}}{ }^{\text {total }}(300$ $\mathrm{K})=0.80)$ [7]や従来の電波透過型熱制御材であるゲルマニ ウム蒸着カプトンの熱光学特性 $\left(\alpha_{\mathbb{N}}{ }^{\text {total }}(\right.$ solar $)=0.45$, $\left.2 \mathrm{~N}^{\text {total }}(300 \mathrm{~K})=0.72\right)$ [8] と比較すると, COSF4-RE は設計值 として十分に排熱材として機能する高機能な材料である ことが分かる.

上記設計結果をもとに, $\mathrm{Ta}_{2} \mathrm{O}_{5}, \mathrm{TiO}_{2}, \mathrm{Si}, \mathrm{SiO}_{2}$ をスパッタ リング成膜した. Figure 7に試作したCOSF4-REの外観を示 す. 大きさは $100 \times 100 \mathrm{~mm}$ である. サンプルの端 $5 \mathrm{~mm}$ に 成膜用治具が装着されている. 外観からはクラックや蒸 着焼け等は確認されなかった.

$0.25 \sim 2.5 \mu \mathrm{m}$ における垂直入射半球反射スペクトル $R_{\mathrm{NH}}(\lambda)$ は, 積分球付ポータブル可視分光光度計（興栄製, PM-A0）を用いて, 室温において測定した。 入射角は $7^{\circ}$
Table 1 Design results of COSF4-RE.

\begin{tabular}{ccccc}
\hline $\begin{array}{c}\text { Thickness, } \\
\mu \mathrm{m}\end{array}$ & $\begin{array}{c}\text { Number of } \\
\text { layers }\end{array}$ & $\begin{array}{c}\alpha_{\mathrm{N}} \text { total } \\
(\text { solar })\end{array}$ & $\begin{array}{c}\varepsilon_{\mathrm{N}} \text { total } \\
(300 \mathrm{~K})\end{array}$ & $\begin{array}{c}\varepsilon_{\mathrm{H}} \text { total } \\
(300 \mathrm{~K})\end{array}$ \\
\hline \hline 3.72 & 34 & 0.05 & 0.80 & 0.74 \\
\hline
\end{tabular}

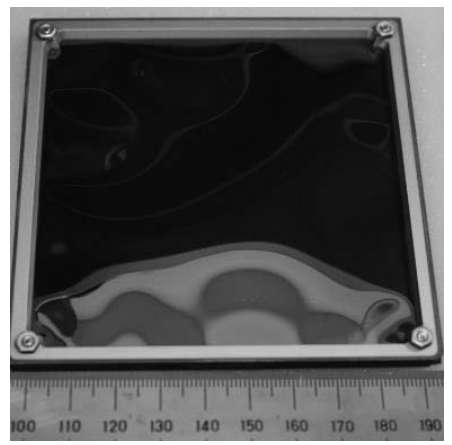

Fig. 7 Photograph of COSF4-RE.

\section{3. 測定方法}

とし，近似的に垂直入射とみなしている．リファレンス材 にはアルミニウムミラー (シグマ光機製) を用いた. 1.67 $\sim 100 \mu \mathrm{m}$ における垂直入射半球反射スペクトル $R_{\mathrm{NH}}(\lambda)$ は, 赤外分光光度計（DEGILAB 製，FTS-3100）を用いて室温 において測定した。この波長域は $173 \sim 373 \mathrm{~K}$ の黒体ふく 射エネルギーの 98 \%以上を占めている. 分光器および試 料室は, 窒素ガスで置換することにより, 空気中の二酸化 炭素・水蒸気による吸収を極力防いでいる. 入射角は $20^{\circ}$ とし，近似的に垂直入射とみなしている．また， $\operatorname{COSF} の$ 場合, 鏡面反射が主で, 拡散反射は十分に小さいことから 近似的に半球反射とみなしている.リファレンスにはゴ ールドミラー (シグマ光機製) を使用した.

全半球放射率 $\&_{\mathrm{H}}{ }^{\text {total }}(T)$ は，カロリーメータ法によって測 定した[9]. Figure 8 に測定装置の概要図を示す. 測定試料 は内径 $600 \mathrm{~mm}$, 全長 $800 \mathrm{~mm}$ の黒色塗料が塗布された真 空チャンバー内に線径 $50 \mu \mathrm{m}$ のコンスタンタン線からな る電力供給線 2 本, 端子電圧測定線 2 本, 及び線径 $50 \mu \mathrm{m}$ の $\mathrm{K}$ 型熱電対によって吊り下げられており, 試料に内蔵 された $30 \mathrm{~mm}$ 角のシートヒータに外部から電力を供給し て平衡温度に維持している. Figure 9 に試料の構成を示す. 試料は片面と側面は全半球放射率が既知のアルミニウム 蒸着フィルムが貼り付けられており，一面のみ試料が接 着されている. 実験では, 標準試料としてアルミニウム蒸 着フィルムの全半球放射率の測定を事前に行うことで, 装置の健全性及び各線からのヒートリーク量を確認して 


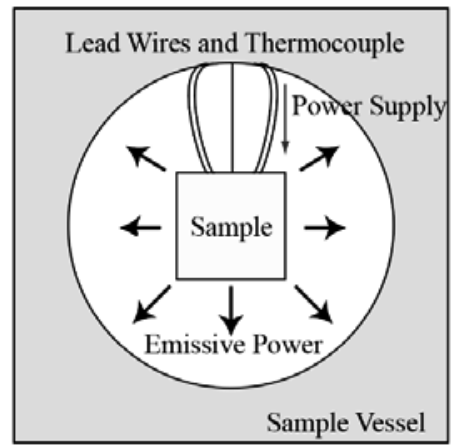

Fig. 8 Schematic diagram of total hemispherical emittance measuring apparatus.

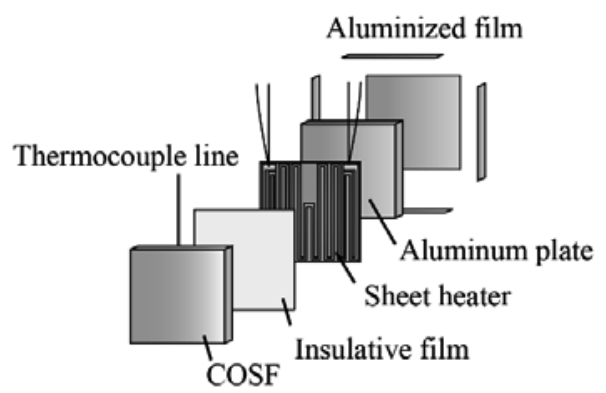

Fig. 9 Sample structure in total hemispherical emittance measuring apparatus.

いる. また, $10^{-4} \mathrm{~Pa}$ 以下の高真空に保ち, シュラウドを液 体窒素によって $77 \mathrm{~K}$ に維持した状態で測定を行った。試 料の全半球放射率 $\varepsilon_{\mathrm{H}}$ total $(T)$ はq. (4)で表される. 測定不確 かさは土2\%以下である.

$$
\varepsilon_{\mathrm{H}}^{\text {total }}(T)=\frac{P-P_{\mathrm{w}}}{\sigma \cdot A_{\mathrm{S}}\left(T^{4}-T_{\mathrm{w}}^{4}\right)}-\frac{A_{\mathrm{Al}}}{A_{\mathrm{S}}} \cdot \varepsilon_{\mathrm{H}-\mathrm{Al}}^{\text {total }}(T)
$$

\section{4. 測定結果}

Figure 10にCOSF4-REの設計および測定した垂直入射半 球反射率 $R_{\mathrm{NH}}(\lambda)$ を示す. 設計值と測定值のスペクトルは良 好に一致していることが分かる. 太陽光吸収率の設計值 は $0.05 に$ 対し，測定值 0.05 と良好に一致した。 また，赤外 放射波長域について考察すると，短波長領域では良好に 一致しているが，30 $\mu \mathrm{m}$ 以降では，測定反射率が大きい值 を示した. この波長域では, 光学定数に文献值を用いたた め，実際の值とは異なると予想される．300 Kにおいて全 垂直放射率の設計值は 0.80 に対し，測定値0.77を示した。 全垂直放射率は設計值と比べて 0.03 減少したが， $300 \mathrm{~K} ゙$
の黒体ふく射エネルギー $I_{\mathrm{B}}$ のピークは $10 \mu \mathrm{m}$ 付近にあり， その領域での反射率が良好に一致していたため，全垂直 放射率の乘離は小さい值となった。

Figure 11 に COSF4-RE の全半球放射率の測定結果を示 す。全半球放射率の設計值と測定值は高温領域で一致し ている一方，低温領域では測定值が下回っていることが

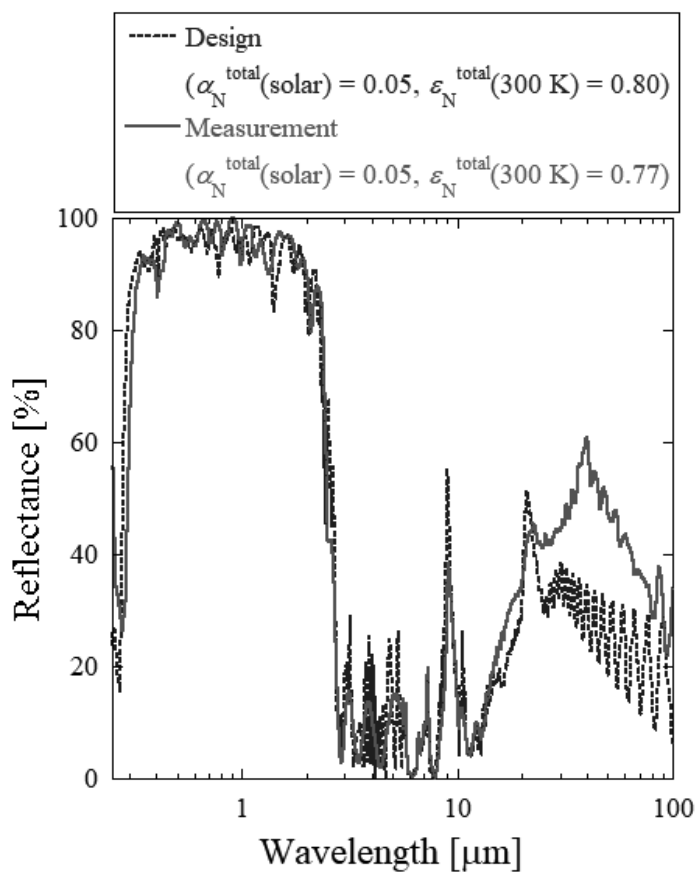

Fig. 10 Measurement and design results of spectral reflectance of COSF4-RE.

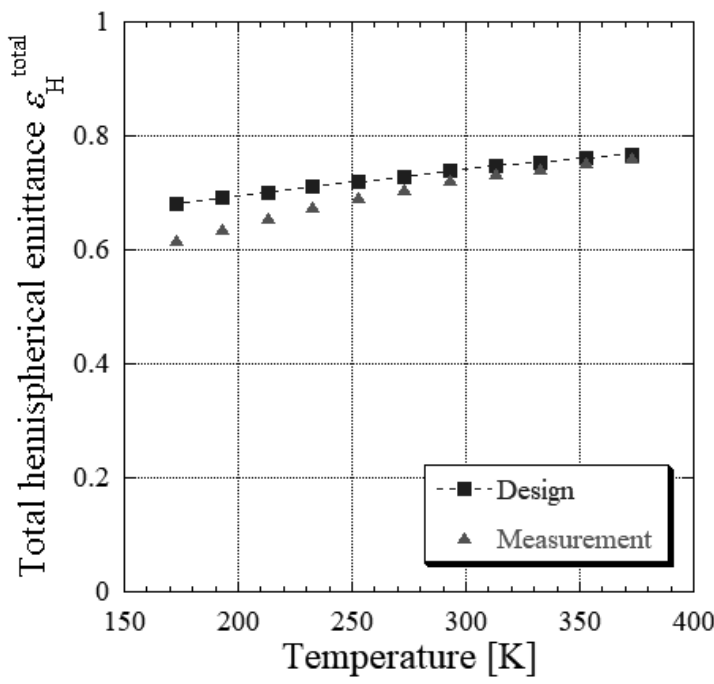

Fig. 11 Measurement and design results of total hemispherical emittance of COSF4-RE. 
Table 2 Measurement results of thermo-optical properties at $T=300 \mathrm{~K}$.

\begin{tabular}{|c|c|c|c|}
\hline & $\alpha_{\mathrm{N}}^{\text {total }}$ & $\varepsilon_{\mathrm{H}}^{\text {total }}$ & $\alpha_{\mathrm{N}}{ }^{\text {total }} / \varepsilon_{\mathrm{H}}^{\text {total }}$ \\
\hline COSF4-RE & 0.05 & 0.72 & 0.07 \\
\hline $\begin{array}{c}\text { Ge-coated } \\
\text { Kapton }\end{array}$ & 0.45 & $\left(\varepsilon_{\mathrm{N}}^{\text {total }}: 0.72\right)$ & $\begin{array}{c}\left(\alpha_{\mathrm{N}}{ }^{\text {total } /} / \varepsilon_{\mathrm{N}}{ }^{\text {total }}:\right. \\
0.63)\end{array}$ \\
\hline OSR & 0.07 & 0.80 & 0.09 \\
\hline
\end{tabular}

分かる. これは垂直入射半球反射率の測定結果が示すよ うに，プランクの法則から高温域で影響する短波長域で の赤外放射波長域の反射率がほぼ一致しているのに対し， 低温側で影響する長波長領域での反射率について測定值 が設計值を上回っていることが原因である．全半球放射 率の設計值は $300 \mathrm{~K}$ において 0.74 であったのに対し, 測 定値は 0.72 となった.

本研究で試作した COSF4-RE と従来熱制御材との比較 を Table 2 に示す. COSF4-RE は, 電波透過性能を備えな がら，従来電波透過型熱制御材として使われてきたゲル マニウム蒸着カプトンやOSR と比べて低い太陽光吸収率 を示している. また, 放射率に関しては同等の高い值を示 している. COSF4-RE の $\alpha_{\mathbb{N}}{ }^{\text {total } /} \mathcal{E}_{\mathrm{H}}^{\text {total }}$ は 0.07 であり， OSR と比べて $22 \%$ 程度低い值を示す.

\section{5.おわりに}

COSF4-REは低太陽光吸収率および高放射率を目標と して開発した排熱用電波透過性型熱制御材料である. 使 用する薄膜材料の光学定数測定を新たに行い，また，薄膜 の光学特性を最大限に生かすように遺伝的アルゴリズム を使って設計することで，太陽光吸収率 0.05 , 全半球放射 率 $(300 \mathrm{~K})$ 0.74を示す優れた材料を設計出来た. 測定值と しては，太陽光吸収率が 0.05 , 全半球放射率 $(300 \mathrm{~K})$ が 0.72を示すことが分かり, 他の熱制御材と比べて高機能で あると言える. 宇宙空間では, 電子線や陽子線などの強力 な放射線が照射される環境であるが，同じ薄膜材を使っ た別のCOSFに関して，而放射線性能が高い熱制御材であ ることが地上試験から明らかになっており [10], 今回試作 したCOSF4-REも同様に耐久性があると予想される。一方， 実際の宇宙環境はUV, 熱ストレス, AOなどが加わった複 合環境であるため, 予想しない劣化現象が生じる可能性 がある. そこで現在, 小型衛星や国際宇宙ステーションの 実験棟暴露部に搭載し，軌道上試験[11]を行っている.

\section{[謝辞]}

本研究の必要経費の一部は, 科研費 (20K14948) の助 成を受けたものであることを記し，謝意を表す。

\section{NOMENCLATURE}

$A_{\mathrm{Al}} \quad:$ Surface area of aluminized film, $\mathrm{m}^{2}$

$A_{\mathrm{S}} \quad$ : Surface area of sample, $\mathrm{m}^{2}$

$\alpha_{\mathrm{N}}{ }^{\text {total }} \quad$ : Normal incidence total solar absorptance

$\alpha_{\mathrm{N}}^{\text {partial }}:$ Normal incidence partial solar absorptance

E $\quad$ : Merit function

$\varepsilon_{\mathrm{H}}^{\text {total }}:$ Total hemispherical emittance

$\varepsilon_{\mathrm{H}-\mathrm{al}}^{\text {total }} \quad:$ Total hemispherical emittance of aluminize film

$\varepsilon_{\mathrm{N}}{ }^{\text {total }} \quad:$ Total normal emittance

$I_{\mathrm{B}} \quad:$ Intensity of blackbody radiation, $\mathrm{W} /\left(\mathrm{m}^{3} \cdot \mathrm{sr}\right)$

$J \quad$ : Intensity of solar radiation, $\mathrm{W} /\left(\mathrm{m}^{3} \cdot \mathrm{sr}\right)$

$\lambda \quad$ : Wavelength in vacuum, $\mu \mathrm{m}$

$P \quad$ : Heater power, $\mathrm{W}$

$P_{\mathrm{w}} \quad:$ Heat loss, W

$\theta \quad$ : Incident angle, deg

$R_{\mathrm{NH}} \quad:$ Normal incidence hemispherical reflectance

$\sigma \quad$ : Stefan-Boltzmann constant, $5.67 \times 10^{-8}$ $\mathrm{W} /\left(\mathrm{m}^{2} \cdot \mathrm{K}^{4}\right)$

T : Temperature, $\mathrm{K}$

$T_{\mathrm{w}} \quad:$ Temperature of wall, $\mathrm{K}$

\section{参考文献}

[1] S. Tachikawa, K. Matsumoto and A. Ohnishi, "Study on Optical Surface Controlled Film for Spacecraft Thermal Control", Proc.30th Jpn. Symp. Thermophys. Prop., (2009), 4-6.

[2] K. Tomioka, S. Tachikawa, K. Kawahara, Y. Nagasaka, "Design and measurement of radiowave transmissive thermal control mirror", J. Spacecraft and Rockets, 53-6 (2016), 1043-1050.

[3] E. D. Palik, "Handbook of Optical Constants of Solids", Academic Press, (1985).

[4] K. Fukuzawa, A. Ohnishi, Y. Nagasaka, "A Prediction of Thermal Radiation Properties of Multilayer Thermal Control Material Based upon Polyimide Film for Space Use”, J. Jpn. Soc. Aeronaut. Space Sci., 50-579, (2002), 129-134.

[5] D. E. Goldberg, D. E., "Genetic Algorithms in Search, Optimization, and Machine Learning", Addison-Wesley, (1989).

[6] M. P. Thekaekara, "The solar constant and the solar 
spectrum measured from a research aircraft", NASA TR R-

351 (1970).

[7] D. G. Gilmore, "Spacecraft Thermal Control Handbook 2nd ed.", Aerospace Corporation, (2002).

[8] The red book, Sheldehl materials:

http://www.sheldahl.com/sites/default/files/Documents/Shi eldingMaterials/RedBook.pdf, (accessed 2020-10-14).

[9] A. Ohnishi, T. Hayashi and H. Nagano, "Measurement of Hemispherical Total Emittance of Thermal Control Materials for Spacecraft”, Proc.4th Jpn. Symp. Thermophys. Prop., (1983), 1-4.

[10] S. Tachikawa, K. Tomioka and Y. Nagasaka, "Thermal control materials by multi-layer film", Proc.39th Jpn. Symp. Thermophys. Prop., (2018), 235-237.

[11] S. Tachikawa and K. Tomioka, "Space Environment Exposure Test for Highly Functional Thermal Control Materials”, Aeronaut. Space Sci. Jpn., 68-5 (2020), 142148.

[Received Oct. 23, 2020, Accepted Dec. 11, 2020] 